\title{
Cost and returns of stall fed and grazing methods of sheep and goat rearing in Dharwad district
}

\author{
B. Priyanka and C. Murthy
}

Received : 26.07.2019; Revised : 01.09.2019; Accepted : 15.09.2019

\begin{abstract}
The investigation was carried out to estimate the cost and returns of stall fed and grazing methods of sheep and goat rearing in Dharwad district 2018-19. The multistage random sampling technique was selected for the study. For the study, in Dharwad district 2 taluks namely, Dharwad and Navalgund taluk were purposively selected to throw light on the study. These 2 taluks have highest number of sheep and goat population and stall fed units in the study area. From each taluk, 8 villages and 3 stall fed units were selected for the study. The cost and returns of stall fed and grazing methods of sheep and goat rearing were analysed in tabular analysis. The investment for stall method of sheep and goat rearing is Rs. 24,77,000 and Rs. 3,630 in case of grazing method of sheep and goat rearing. The study reveals that the variable cost, fixed cost and total cost of rearing were highest on stall fed method of sheep and goat rearing, followed by grazing method of sheep and goat rearing. The maximum returns are from the sale of animal followed by sale of manure.
\end{abstract}

KEY WORDS : Stall fed, Grazing, Water tub, Chaff cutter, Temporary fence, Cost, Returns, Manure, Sale of sheep, Goat, Sale price

How to cite this paper : Priyanka, B. and Murthy, C. (2019). Cost and returns of stall fed and grazing methods of sheep and goat rearing in Dharwad district . Internat. J. Com. \& Bus. Manage, 12(2) : 37-45, DOI: 10.15740/HAS/IJCBM/12.2/37-45. Copyright@ 2019: Hind Agri-Horticultural Society. 